\title{
PENGEMBANGAN MATHEMATICAL MAPLE BERBASIS KOOPERATIF THINK-PAIR-SHARE UNTUK MENINGKATKAN KEMAMPUAN REPRESENTASI MATEMATIS MAHASISWA DAN KUALITAS PERKULIAHAN FISIKA MATEMATIK
}

\author{
Edy Tandililing \\ Pendidikan Fisika Jurusan PMIPA FKIP UNTAN \\ edytandi@yahoo.co.id
}

\begin{abstract}
The main purpose of research is whether the representation of mathematical ability of students increased after learning gained through the program Mathematical Maple combined with cooperative learning Think Pair Share on lectures of Mathematical Physics. Subjects were students of third semester of physical education courses with the number of 35 students. The method used is a Class Action Research conducted through three cycles or actions which each cycle. The research instrument consists of: test, questionnaire, and observation guidelines. Based on data analysis concluded: (1) the ability of the representation of the students in understanding the meaning of the physical, the ability of representation of students to represent the mathematical equation in the form of graphs, the ability of the representation of the students in giving meaning physical on the results of visualization, and the ability of the representation of the students in understanding the course materials Mathematical Physics increase in each cycle or action; (2) the implementation process using computer-aided applications maple in the first cycle having problems because the students have never known the computer-assisted program maple, but in the next cycle students were able to adjust the maple program that is being used; and (3) the response of students to the course of action given the overall increase in each cycle.

Keywords: Ability Representation, Think Pair Share.
\end{abstract}

$\begin{array}{lllr}\text { Fisika adalah salah satu } & \text { dinyatakan dalam bentuk } \\ \text { cabang ilmu pengetahuan alam } & \text { angka.Dengan karakteristik ini, } \\ \text { (sains) yang pada dasarnya bertujuan } & \text { pembahasan fisika selalu dikaitkan } \\ \text { untuk mempelajari dan memberi } & \text { dengan masalah pengukuran.Dari } \\ \text { pemahaman kuantitatif } & \text { pengukuran ini dapat diperoleh data } \\ \text { terhadapberbagai gejala atau proses } & \text { yang selanjutnya dianalisis untuk } \\ \text { alam. Pendekatan yang digunakan } & \text { menjelaskan } & \text { hubungan } \\ \text { biasanya adalah memadukan hasil } & \text { antarkonsep.Untuk menjelaskan } \\ \text { percobaan dan analisis } & \text { konsep fisika matematika memegang } \\ \text { matematis.Sebagai salah satu cabang } & \text { peranan yang sangat penting. } \\ \text { sains, salah satu karakteristik fisika } & \text { Rumusan matematis akan } \\ \text { adalah kuantitatif.Pada dasarnya } & \text { memberikan kesederhanaan dalam } \\ \text { semua konsep fisika selalu dapat } & \text { memerikan konsep maupun }\end{array}$


memudahkan dalam memahami gejala fisika. Matematika merupakan alat yang paling ampuh untuk menjelaskan gejala fisika.

Matematika juga memegang peranan penting untuk menunjang proses perkuliahan fisika di Perguruan Tinggi. Dengan kata lain, matematika merupakan alat atau instrumen untuk mempelajari fisika. Idealnya, sebelum belajar suatu pokok bahasan fisika mahasiswa sudah memahami beberapa konsep dasar matematika yang diperlukan untuk memudahkan pemahaman pokok bahasan itu. Sebagai contoh, mahasiswa belajar tentang kecepatan dan percepatan sesaat.Untuk membahas kedua besaran ini, konsep limit fungsi dalam matematika tentunya harus diketahui oleh mahasiswa.

Fisika

matematik

(mathematical physics) atau matematika untuk fisika membahas secara terpadu dan sistematis matematika yang digunakan dalam fisika.Ilmu ini berkaitan erat dengan fisika teori yang berupaya menelusuri hukum-hukum alam secara matematis.Dengan mempelajari fisika matematik, konsep fisika dapat dipahami secara menyeluruh dan terpadu.Secara umum, fisika matematik mempelajari tentang deret takhingga, prsamaan diffrensial, integral bilangan kompleks, aljabar linear, diferensial parsial, analisis vector,masing-masing penerapannya dalam fisika dan lain-lain.

Perkuliahan Fisika

Matematika (FISMAT) memberikan dasar-dasar penguasaan metode matematika yang digunakan dalam membahas gejala fisis alam.Pada dasarnya, setiap permasalahan atau fenomena dapat diekspresikan secara matematis yang merupakan suatu model matematik dari masalah tersebut, sehingga dengan model matematik ini dapat dipelajari perilaku permasalahannya. Pemodelan gejala fisika yang tergambar dalam persamaan matematis itu, kadang menimbulkan kesulitan bagi mahasiswa untuk bisa melihat dan memberi makna fisis dari fenomena alam yang sesungguhnya terjadi. Melalui penelitian ini akan dikaji apakah dengan visualisasi dengan menggunakan aplikasi program Mathematical Applet (Maple) dapat meningkatkan kemampuan representasi matematis dalam pemahaman materi perkuiahan fisika matematik di semester III, khususnya pokok bahasan Integral dan Persamaan Differensial Biasa

Fisika matematik adalah salah satu mata kuliah wajib bagi mahasiswa prodi pendidikan fisika baik kelas reguler maupun kelas PGMIPA unggulan.Mata kuliah ini tergolong mata kuliah perkakas, sehingga materi perkuliahan yang disajikan adalah berbagai metode dan teknik matemaika sebagai alat bantu dalam mempelajari berbagai materi perkuliahan fisika. Mahasiswa diharapkan memiliki wawasan pengetahuan dan pemahaman yang baik terhadap berbagai metode dan teknik fisika matematika.

Pengalaman mengampuh mata kuliah fisika matematik selama 6 tahun terakhr menunjukkan bahwa penguasaan mahasiswa tentang konsep atau ide-ide kalkulus yang mendasari fisika matematik (fismat) masih terlalu sempit, belum multireprentasi, dan bersifat prosedural.Akibat ketidakmampuan 
mahasiswa memahamikonsep-konsep matematika secara multi-reprentasi, mereka mengalami kesulitan dalam memahami konsep-konsep dalam Fismat. Walaupun kelihatannya kompleks, ide-ide Fismat sebenarnya tetap sama dengan ide-ide kalkulus yang sudah dipelajari sebelumnya. Untuk menunjukkan kelemahan yang telah disebutkan, tes di berikan kepada 40 orang mahasiswa semester 4 yang sudah mengikuti perkuliahan Fisika matematik. Tes tersebutterdiri dari soal-soal berikut.

Selesaikanlah soal berikut
a. $\int_{-1}^{1} \frac{1}{x^{2}} d x$
b. $\int_{2}^{5} / x-5 / \mathrm{dx}$.

Adaptasi dari Gede Suweken, (2012)

\section{Berdasarkan}

jawaban

mahasiswa pada soal (a) hanya 5 mahasiswa dari 40 mahasiswa yang menjawab benar sedangkan pada soal (b) hanya 8 mahasiswa yang menjawab benar. Pengamatan terhadap jawaban yang diberikan oleh mahasiswa terhadap kedua soal ini menunjukkan bahwa kelemahan mahasiswa masih tetap sama. Soal (a), misalnya, hanya dijawab secara prosedural dan analitik, tanpa pernah menyadari apakah jawaban yang diberikan masuk akal (making sense) atau tidak. Pada soal (a) mahasiswa menyelesaikan seperti berikut:

$$
\begin{aligned}
& \int_{-1}^{1} \frac{1}{x^{2}} d x \quad=\int_{-1}^{1} x^{-2} d x= \\
& \int_{-1}^{1} \frac{1}{-2+1} x^{-2+1} d x=-1 \int_{-1}^{1} x^{-1} \mathrm{dx}= \\
& \frac{-1}{x} \mid=-1-1=-2
\end{aligned}
$$

Mengingat fungsi $\frac{1}{\mathrm{x}^{2}}$ adalah fungsi yang definit positif, seluruh grafiknya berada diatas sumbu x.Karena integral dari suatu fungsi menunjukkan luas daerah maka mahasiswa seharusnya mencurigai hasil negatif yang diperoleh diatas tentu saja tidak ada luas daerah yang negatif.

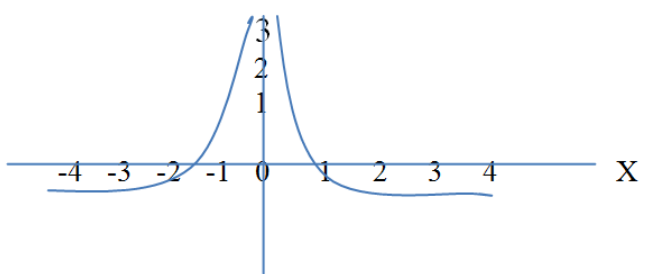

Gambar 1. Grafik fungsi $y=1 / x^{2}$

Jawaban terhadap soal (b) sebagian besar juga bersifat analitikprosedural.Dari 40 orang mahasiswa, hanya 10 mahasiswa menjawab soal dengan benar dengan menyertakan grafik.Beberapa mahasiswa dapat memahami konsep harga mutlak dengan baik, tetapi mereka gagal memberikan jawaban benar karena tidak menyesuaikan batas-batas integrasi yang berjalan defenisi fungsi harga mutlak tersebut.Fungsi harga mutlak adalah fungsi yang agak kompleks jika di dekati secara analitik.Grafik fungsi harga mutlak sebenarnya tidak terlalu sulit untuk di gambar, tetapi mahasiswa tidak pernah menyadari bahwa grafik biasa menjadi alat ampuh untuk menyelesaikan suatu soal.Hal ini di sebabkan oleh pemahaman mahasiswa yang hanya bersifat analitik dan prosedural. 


\section{Pengembangan Mathematical Maple48}

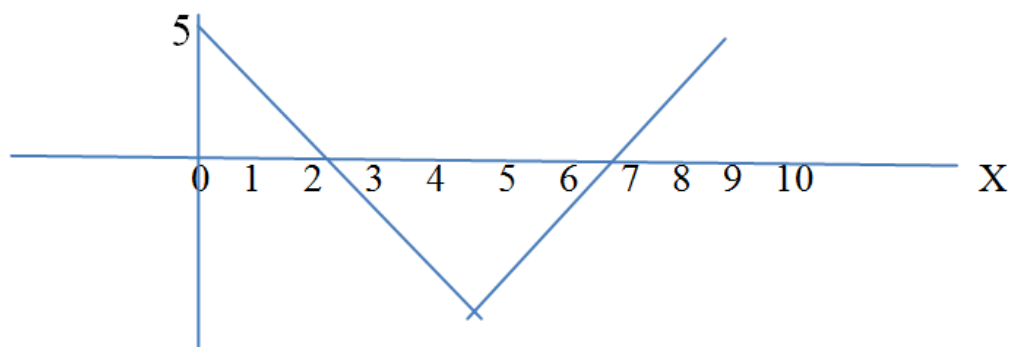

Gambar 2 : Grafik fungsi $\mathrm{y}=/ \mathrm{x}-5 /$

Jika representasi visual di manfaatkan dalam menyelesaikan soal di atas, mungkin di perlukan waku 5 menit saja untuk menyelesaikannya secara benar. Penggunaan pendekatan visual dalam menyelesaikan soal-soal di atas akan memberikan hasil tidak ada jawaban ( $\infty$ ) untuk soal (a), Jadi, kedua soal di atas benar-benar hanya memerlukan kemampuan visual dalam menjawabnya.

Analisis terhadap jawaban mahasiswa di atamsagandejgiasilnaønunjukkapekggmahan mahasiswa dalam ma pada mata kuliah kalkulus atau matematika dasar, tetapi juga pada kuliah fisika matematik.Kelemahankelemahan yang disebutkan harus diatasi agar mereka bisa mengikuti perkuliahan fisika matematik dengan sukses. Selain itu,sangat penting bagi mahasiswa sebagai calon guru fisika untuk menyadari bahwa konsepkonsep matematika harus di pahami secara multi-representatif dan bermakna, tidak di hafal begitu saja. Pemahaman mahasiswa pendidikan fisika yang baik, komprehensif, dan multi-representati terhadap konsepkonsep matematika merupakan modal dasar bagi mereka untuk bisa membelajarkan matematika dengan baik kepada siswa di sekolah menengah. Karakteristik matematika sekolah, yaitu: (1) matematika sebagai kegiatan penelusuran pola dan hubungan, (2) matematika sebagai kreativitas yang memerlukan imajinasi, intuisi, dan penemuan, (3) matematika sebagai kegiatan pemecahan masalah (problem solving), dan (4) matematika sebagai alat berkomunikasi (NCTM, 2000). Hal ini memerlukan pemahan konsep yang baik, komprehensif dan multirepresentatif.

Bagaimana mengatasi kelemahan mahasiswa yang memandang bahwa matematika hanya secara analitik-prosedural?Salah satu caranya adalah dengan mathlet dalam perkuliahan FISMAT. Yang dimaksud dengan mathlet dalam penelitian ini adalah mathematical applet, yakni media pembelajaran berbasis komputer yang tidak terlalu besar yang dirancang khusus untuk membantu mahasiswa melakukan eksplorasi terhadap suatu konsep matematika tertentu. Pembelajaran matematika seharusnya bersifat eksploratif, artinya konsepkonsep yang hendak dibelajarkan tidak diberikan dalam bentuk yang sudah jadi, melainkan melalui suatu masalah yang harus di eksplorasi secara dinamik oleh mahasiswa. Dengan pembelajaran seperti ini, keterlibatan mahasiswa dalam pembelajaran diharapkan meningkat pada akhirnya akan membuat konsep yang dipelajari menjadi lebih bermakna, lebih kaya, lebih lama diingat dan lebih siap untuk diaplikasikan dibidang lain. Pembelajaran eksploratif barbantuanmathlet diharapkan akan 
dapat meningkatkan kualitas perkuliahan FISMAT. Pengalaman belajar seperti ini tentu akan menjadi modal dasar bagi mahasiswa calon guru fisika dalam membelajarkan kemudian hari.

Berdasarkan atas kajian teori yang relevan dan beberapa hasil penelitian, tindakan yang dipandang paling relevan untuk memecahkan masalah yang dialami mahasiswa dalam perkuliahan FISMAT adalah dengan cara membelajarkan mereka secara eksploratif dengan bantuan methlet. Selain itu, untuk lebih menyempurnakan proses eksplorasi dan pengkontruksian konsep, proses pemaknaan dan proses terhadap konsep-konsep yang dipelajari pembelajaran berbantuan methlet diatas dilakukan mahasiswa secara kooperatif think-pair-share.Pertamatama masalah disajikan untuk memotivasi mahasiswa berpikir (think).Setelah itu, mahasiswa membentuk pasangan (pair) untuk melakukan eksplorasi terhadap masalah yang diberikan dengan bantuan methlet. Dengan berpasangan seperti ini, mahasiswa diharapkan bisa saling memberi dan menerima (sharing) pendapat atau ide dalam proses pengkontruksian dan pemaknaan konsep-konsep yang dipelajari. Proses diskusi, mempertahankan pendapat, dan menyanggah pendapat teman yang menjadi pasangan dapat mempertajam pemahaman mereka terhadap konsep yang sedang dipelajari. Akhirnya, pemahaman yang telah dicapai pada tingkat pair dipertajam lagi pada tingkatan yang lebih luas melalui presentasi hasil (share) pada tingkat kelas. Dengan demikian, melalui pembelajaran eksploratif berbasis methlet bersetting kooperatif think-pair-share mahasiswa diharapkan dapat: (1) menyadari bahwa konsep matematika bersifat multi-representatif , (2) memaknai konsep-konsep fisika matematika dengan baik tidak hanya dihapal, meningkat keterlibatannya dalam perkuliahannya, dan (4) memahami konsep-konsep Fismat pada khususnya dan pada matematika pada umumnya.

Kegiatan Penelitian Tindakan
Kelas ini bertujuan untuk
meningkatkan kemampuan
representasi matematis mahasiswa
dan kualitas proses perkuliahan yang
diimplementasikan pada mata kuliah
fisika matematika (Fismat) di
program studi pendidikan fisika.

\section{Metode}

Penelitian ini merupakan penelitian tindakan kelas (PTK) untuk mengungkap kemampuan representasi matematis mahasiswa memahami materi fisika matematika yang mengikuti perkuliahan Fismat sekaligus meningkatkan kualitas perkuliahan. PTK yang dilakukan terdiri atas 3 siklus dengan setiap siklus terdiri dari 4 tahap, yaitu (1) penentuan masalah dan perencanaan tindakan untuk pemecahannya, (2) pelaksanaan tindakan yang sudah direncanakan, (3) observasi dan evaluasi terhadap yang sudah dilakukan, dan (4) refleksi terhadap hasil yang dicapai untuk selanjutnya bisa dilakukan perbaikan pada tindakan berikutnya. Refleksi awal tentang kendala-kendala yang dialami selama ini dalam perkuliahan FISMAT mengawali pelaksanaan PTK ini.Refleksi awal ini 
menghasilkan perumusan yang pemecahannya dicari melalui penelitian ini.

Subyek penelitian adalah mahasiswa semester III prodi Pendidikan fisika jurusan PMIPA yang mengikuti perkuliahan Fisika Matematika pada semester ganjil tahun kuliah 2014 dengan jumlah 35 mahasiswa yang terdiri dari 18 mahasiswa putra dan 17 mahasiswa putri. Faktor yang diteliti dalam penelitian ini adalah: (1) Kemampuan untuk merepresentasikan persamaan matematis dalam bentuk grafik,(2)Kemampuan memberikan makna fisis pada hasil visualisasi grafik., (3) Hasil belajar (aspek kognitif) dan (4) Aspek afektif seperti: kendala dalam mengintegrasikan perkuilahan, respon mahasiswa, dan tinggkat keterlibatan mahasiswa

\section{A. Instrumen penelitian}

1. Pedoman observasi. Pedoman observasi digunakan agar peneliti dapat melakukan pengamatan sesuai dengan tujuan penelitian. Pedoman observasi berisi aspek-aspek yang berkaitan dengan rencana tindakan, pelaksaan tindakan, dan evaluasi sesuai dengan tujuan penelitian.Pedoman observasi tetang keterlibatan mahasiswa dalam perkuliahan terdiri atas lima perilaku yang dapat di amati, yatu:

(1) sikap ketika mengikuti perkuliahan , (2) perhatian terhadap perkuliahan , (3) tanggung jawab, (4) partisipasi dalam perkuliahan, dan (5) kesiapan mengikuti evaluasi. Setiap perilaku ini dideskripsikan oleh 4 deskriptor, yang masing masing memiliki skor 1 sampai dengan 4. Skor 1 adalah skor untuk perilaku yang paling diharapkan. Instrumen ketiga berupa kuesioner.Instrumen ini disusun dengan menggunakan skala Likert yang diaksudkan untuk mengetahui respon mahasiswa terhadap tindakan yang telah diberikan.

2. Tes

Tes yang digunakan pada setiap siklus terdiri dari masingmasing 4 soal uraian yang menyangkut indikator kemampuan representasi matematis. Tes ini diberikan setiap akhir siklus pada perkuliahan. Aspek dalam penilaian adalah selain tes kognitif (mampu menjawab pertanyaanpertanyaan yang diberikan), juga tes sikap (afektif).Tes hasil belajar digunakan untuk mengukur kemampuan representasi matematis, kemampuan memaknai konsep, dan tingkat pemahaman mahasiswa tehadap konsep-konsep Fismat.

3. Catatan Lapangan

Catatan lapangan

merupakan satu di antara cara untuk melaporkan hasil observasi, refleksi, dan reaksi terhadap masalah-masalah kelas. Catatancatatan ini ditulis sesegera mungkin setelah perkuliahan usai. Hal ini dilakukan dengan tujuan agar semua peristiwa dapat terangkum dengan cepat tanpa khawatir ada peristiwa yang hilang.

B. Analisis Data

Analisis data penelitian secara kuantitatif dan kualitatif. Data kuantitatif diperoleh dari kemampuan mahasiswa menjawab tes kemampuan representasi matematis dalam 
memahami konsep Fismat, yang diukur melalui tes hasilperkuliahan. Sedangkan yang merupakan data kualitatifnya adalah data yang berkenaan dengan kegiatan mahasiswa dan kegiatan dosen selama perkuliahan. Data kuantitatif diolah dengan statisik deskriptif. Adapun data kualitatatif dianalisis secara kualitatif, yaitu melalui reduksi data, kemudian dianalisis serta menarik kesimplan sesuai dengan permasalahan penelitian. Indikator keberhasilan apabila skor rata-rata indikator kemampuan representasi mahasiswa setiap siklus meningkat dan adaya peningkatan kualitas perkuliahan Fismat.

\section{Hasil dan Pembahasan}

A. Kemampuan Pemahaman Makna fisis mahasiswa

Rata-rata skor kemampuan mahasiswa pada pemahman makna fisis setiap siklus seperti terlihat pada Gambar 1.

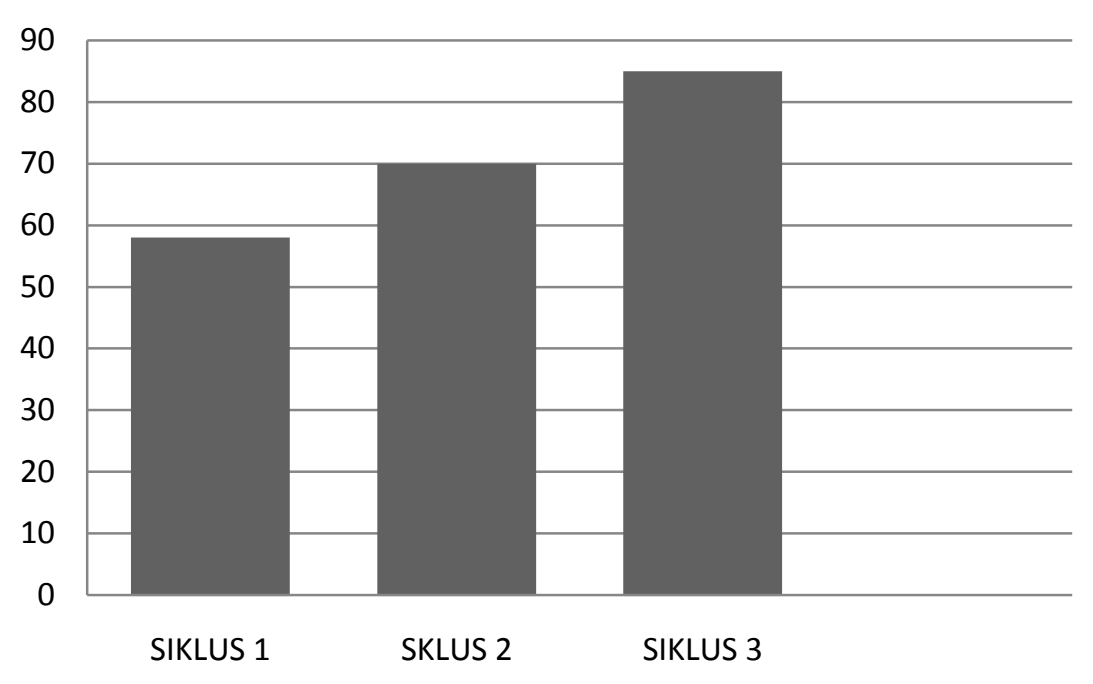

Gambar 1: Grafik Pemahaman Makna Fisis Mahasiswa.

Dari gambar 1 terlihat bahwa kemampuan pemahaman makna fisis mahasiswa mengalami peningkatan. Dengan besarnya skor rata-rata kemampuan tersebut adalah rata-rata skor 58 pada siklus 1, meningkat menjadi rata-rataskor69pada siklus 2, dan rata-rata skor 82 pada siklus 3 . Hal ini tak lepas dari peranan komputer sebagai media yang dipilih oleh pengajar dalam proses pembelajarannya. Penggunaan komputer dalam pembelajaran Sains, sangat menguntungkan karena dapat memberikan kesempatan yang luas kepada mahasiswa untuk

mengembangkan
kemampuannya
dalam investigasi dan analisis
sekaligus dapat membentuk
pengetahuan dan pemahaman yang
baru dalam melihat suatu
permasalahan, serta mendapatkan
cara pemecahan masalahnya.
Serangkaian kegiatan yang telah
dilakukan untuk meningkatkan
kemampuan berpikir tersebut dapat
tercermin dari kegiatan mahasiswa
dalam menganalisis permasalahan
atau identifikasi masalah,
menyelesaikan permasalahan dan
evaluasi serta menggambar grafik
dengan komputer.


Untukmenyelesaikan permasalahan dan membuat grafik dengan benar, mahasiswa harus dapat menuliskan perintah Maple dengan benar. Pada tahap instruksi ini, teori danmasalah yang sedang dipelajari dimasukkan ke dalam komputer guna mendapatkan umpan balik segera. Seperti yang diungkapkan oleh Hamalik (2003:237) bahwa proses yang dilakukan tersebut bermanfaat untukmeningkatkan keterampilan berpikir kritis, logis, dan memecahkan masalah.

Adanya kendalah mahasiswa dalam representasi pemahaman makna fisis pada awal pembelajaran tidak lepas dari ketidakmampuan mahasiswa menggambar atau membuat grafik setiap fungsi yang diberikan. Ary (2006) dalam penelitiannya menyatakan visualisasi bagi mahasiswa kadang kala mendapat kendala dalam melukis grafik dari persamaan suatu fungsi aljabar. Dengan adanya pembelajaran menggunakan maple yang dipadukan dengan Think-Pair-Share memungkinkan mahasiswa secara nyata dalam melukis grafi suatu fungsi.

B. Kemampuan mahasiswa dalam merepresentasikan persamaan matematis dalam bentuk grafik.

Kemampuan mahasiswa untuk merepresentasikan persamaan matematis dalam bentuk grafik setiap siklus ditunjukkan pada Gambar 2 berikut ini.

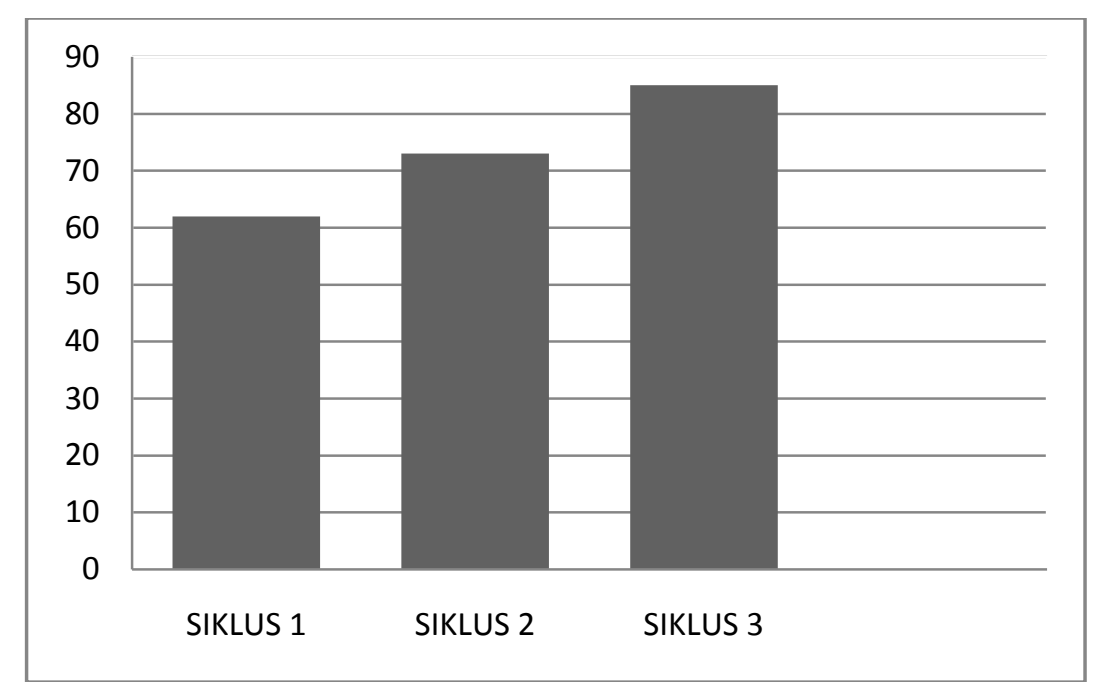

Gambar 2: Grafik Kemampuan Mahasiswa dalam representai Matematis.

Dari gambar 2 terlihat bahwa kemampuan mahasiswa untukmerepresentasikan persamaan matematis dalam bentuk grafik mengalami peningkatan. Besarnya kemampuan tersebut adalah rata-rata 58 pada siklus 1 meningkat menjadi rata-rata 70 pada siklus 2, dan meningkat menjadi rata-rata 79 pada siklus tiga.

Hasil yang diperoleh ini tidak lepas dari usaha mahasiswa untuk menggambar grafik dengan benar. Dengan adanya kesempatan yang banyak dalam berlatih Maple membuat kemampuan mahasiswa tersebut. Disamping perintah (syntax) 
yang cukup singkat, sehingga mudah untuk dipelajari, Maple memang didesain khusus untuk membuat visualisasi, simulasi, dan animasi, yang dapat menggambarkan fenomena atau gejala fisika. Visualisasi yang dibuat dapat meningkatkan pemahaman yang lebih mendalam pada ilmu-ilmu dasar, khususnya fisika. Sepertiyang diungkapkan oleh Tung (2003) bahwa kemampuan Maple untuk mengeksplorasi visual dan grafik dapat diandalkan.
C. Kemampuan mahasiswa dalam memberikan makna fisis pada hasil hasil visualisasi grafik.

Kemampuan mahasiswa dalam memberikan makna fisis pada hasil visualisasi grafik pada setiap siklus dapat dilihat pada Gambar 3.Kemampuan mahasiswa dalam memberikan makna fisis pada hasil visualisasi grafik mengalami peningkatan pada setiap siklus. Ratarata peroleh skor mahasiswa pada siklus satu adalah 57, sedangkan pada siklus 2 rata-rata skor mahasiswa sebesar 67, dan meningkat pada siklus ketiga dengan rata-rata skor 81 .

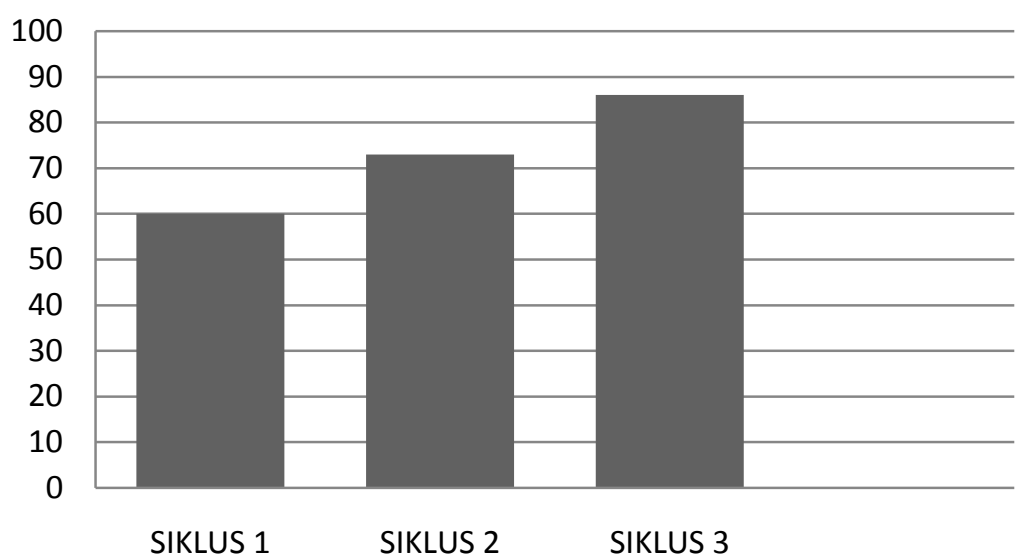

Gambar 3. Grafik Kemampuan Mahasiswa dalam representai makna fisis visualisasi grafik

Melalui serangkaian kegiatan yang dilakukan untuk menyelesaikan masalah dengan baik dan benar akan didapatkan sebuah kesimpulan. Dari gambar 3 terlihat bahwa pada aspek kesimpulan, kemampuan ini terus meningkat dari siklus 1 sampai dengan siklus 3, artinya bahwa mahasiswa tersebut mampu mengunakan akal dan pikirannya untuk menyelesaikan permasalahan dengan baik, sehingga kemampuan berpikir dalam pemahaman makna fisis mahasiswa Fisika pada perkuliahan Fisika Matematika menjadibaik.

D. Pemahaman Mahasiswa Terhadap Materi kuliah Fismat.

Ringkasan rata-rata nilai mahasiswa dalam memahami materi Fismat yang diberikan pembelajaran secara eksploratif berbantuan matple seperti pada Gambar 4 berikut ini. 


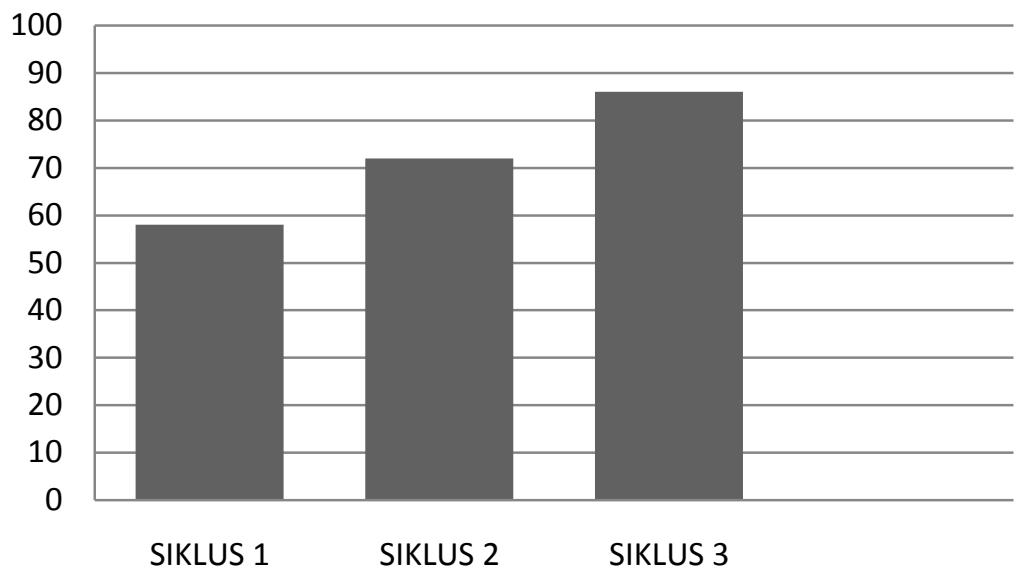

Gambar 4.Skor rata-rata pemahaman mahasiswa dalam memahami konsep Fismat.

Berdasarkan gambar 4 secara umum hasil belajar mahasiswa berupa nilai postest yang diberikan pada setiap akhir siklus dan ketuntasan belajar mengalami peningkatan dari siklus satu ke siklus berikutnya. Pada siklus 1 nilai rata-rata postes mahasiswa sebesar 56 dengan ketuntasan belajar sebesar 25\%. Pada siklus 2 hasil belajar mahasiswa meningkat menjadi 69 dengan ketuntasan 60\%. Hingga akhirnya pada siklus 3 hasil belajar tersebut meningkat menjadi 81 denganketuntasan $85 \%$.

Dengan ketuntasan belajar sebesar $25 \%$ pada siklus pertama ini, berartibahwa hanya $25 \%$ dari seluruh mahasiswa yang memperoleh nilai 56 atau lebih. Pada siklus 1 mahasiswa hanya diberi kesempatan latihan menggunakan Maple untuk menyelesaikan permasalahan. Oleh karena itu pada siklus selanjutnya selain memberikan kesempatan untuk mempelajari Maple, mahasiswa juga diberikan kesempatan untuk menyelesaikan masalah dengan cara analitis yaitu dengan menambahkan latihan di rumah sehingga hasil belajar mahasiswa akan meningkat. Terlihat bahwa pada siklus 2 hasil belajar mahasiswa meningkat menjadi 69 dengan ketuntasan 60\%. Hingga akhirnya pada siklus 3 hasil belajar tersebut meningkat menjadi 81 denganketuntasan $85 \%$. Dengan hasil ini mengindikasikan bahwa mahasiswa telah mampu mengkontruksi pengetahuannya sendiri berdasarkan pengetahuan awal yang dimiliki. Dengan menggunakan media komputer mahasiswa dapat mengeksplorasi kemampuannya untuk mendapatkan pengetahuan yang baru dan untuk menyelesaikan permasalahan.

E. Kendala Pengintegrasian maple dalam Perkuliahan Fismat.

Kendala mahasiswadalam pengintegrasian Maple dalam pembelajaran fismat adalah kurannya pemahaman mahasiswa tentang program computer yang sedang digunakan. Banyak mahasiswa yang dalam pengoperasian program terkendala oleh cara pengoperasian program berbantuan Maple. Khususnya pada siklus 1 banyak mahasiswa yang mengalami kendala ketika mengoperasikan computer di masing-masing laptopnya. 
Di samping itu mahasiswa juga mengalami kendala dalam memahami konsep fisika matematika sebagai akibat dari rendahnya kemampuan matematika dalam memahami konsep dasar fismat.Dalam menginterpretasikan persamaan atau difrensial pada berbagai tingkat seringkali keliru dalam mengerjakan setiap soal yang diberikan.Banyak konsep yang sebenarnya sederhana tapi fundamental belum dimaknai mahasiswa dengan benar.Ketika menyelesaikan soal-soal dengan bantuan program computer maple, disamping mengalami kendala dalam pengoperasian juga mengalami kendala dalam memahami solusi dari persamaan difrensial yang diselesaikan.

Pada siklus 2 mahasiswa sudah mulai merasakan cara pengoperasian program computer maple yang diterapkan pada perkuliahan fisika matematika. Sebagian besar mahasiswa sudah dapat mengoperasikan program dan menyelesaikan persamaan difrensial pada berbagai tingkat. Hanya ada beberapa mahasiswa yang mengalami kesulitan terutama dan menyelaraskan persamaan dengan program kcomputer yang akan dioperasikan. Pada siklus 3 kendala sudah mulai diatasi oleh mahasiswa baik ketika diberi kesempatan untuk latihan maupun pada pengaplikasi program pada persamaan difrensial.Seiring dengan adanya peningkatan mahasiswa dalam mengaplikasikan program terutama dalam persamaan difrensial, juga dibarengi dengan peningkatan multi representasi dan pemahaman mahasiswa dalam perkuliahan fisika matematika di program studi pendidikan fisika.

F. Respon Mahasiswa Terhadap Tindakan Yang Diberikan.

Dari angket yang telah diisi oleh mahasiswa dapat diketahui bahwa mahasiswa menerima model pembelajaran Fisika Matematika I denganmenggunakan aplikasi program Maple. Dari 35 mahasiswa, $18 \%$ mahasiswamerespon dengan sangat positif dan $82 \%$ mahasiswa merespon positif. Hasil ini menunjukan bahwa mahasiswa menikmati dan menyenangi pembelajaran Fisika Matematika dengan menggunakan aplikasi program Maple. Kesenangan mahasiswa tersebut tercermin dari meningkatnya kualitas mahasiswadalam mengerjakan tugas yaitu sebesar 78\%.Dengan hasil ini menunjukan bahwa mahasiswa telah mampu mengkontruksi pengetahuannyasendiri.

Sehinggapencapaian tujuan belajar menggunakan Maple terpenuhi.Dari 35 mahasiswa terdapat 28\% mahasiswa memberikanrespon sangat positif dan $72 \%$ mahasiswa memberikan respon positif.Dengan begitu keterlibatan pengajar dalam pembelajarandapatberkurang.Pengaja $r$ hanya sebagai pembimbing dan pengarah saja, sedangkan mahasiswa aktif belajar sendiri untuk mengkontruksi pengetahuannya.

\section{Simpulan dan Saran}

Berdasarkan hasil penelitian yang dilaksanakan pada penelitian tindakan kelas dan perolehan nilai mahasiswa, dapat disimpulkan sebagai berikut.
1. Kemampuan Representasi
pemahaman matematis 
mahasiswa pada setiap indikator representasi yaitu merepresentasikan persamaan matematis, memberi makna fisis dalam bentuk grafik, memberi makna fisis pada hasil grafik, dan memahami materi perkuliahan fisika matematik meningkat pada setiap siklus yang telah dilakukan.

2. Pelaksanaan perkluliahan fisika matematika menggunakan aplikasi computer berbantuan maple pada siklus pertama mengalami kendala karena mahasiswa belum perna mengenal program computer berbantuan maple. Namun pada siklus berikutnya mahasiswa sudah dapat menyesuaikan program maple yang sedang digunakan.

3. Respon mahasiswa terhadap tindakan yang diberikan pada perkuliahan fisika matematika secara keseluruhan meningkat baik yang respon sangat positif maupun yang respon positif

\section{Daftar Pustaka}

Hamalik, Oemar. 2003. Proses Belajar Mengajar. Jakarta: PT Bumi Aksara.

Gede Suweken, (2012). Eksplorasi Mathlet dan Kooperatif ThinkPair-Share untuk meningkatkan Kualitas Perkuliahan MNASB. Jurnal Pendidikan dan Pengajaran jilid 45 N0.1 (1-10)

Ibrahim, dkk. 2005. Pembelajaran Kooperatif. Surabaya : UNESA University Press.

National Council of Teacher of Mathematics (NCTM). (2000). Reasoning and Proof for Grade 3-5. Principles and Standards for School Mathematics. Reston, VA: The National Council of Teachers of Mathematics, Inc. 